\title{
Efficacy of Two lodine Teat Dips Based on Reduction of Naturally Occurring New Intramammary Infections
}

\author{
C. J. Foret, ${ }^{1}$ C. Corbellini, ${ }^{2}$ S. Young, ${ }^{3}$ and P. Janowicz ${ }^{1}$ \\ ${ }^{1}$ DeLaval Inc., Kansas City, MO 64153 \\ ${ }^{2}$ Proyecto Lechero, E.E.A INTA Pergamino, Buenos Aires, Argentina \\ ${ }^{3}$ PONCYT, Proyecto BID 1201-OC-AR-PICT 08-03371
}

\section{ABSTRACT}

The efficacy of 2 teat dips, product 1 (Della Care with 5 to $8 \mathrm{ppm}$ of free iodine, used as a positive control) and product 2 (New Della Care with 12 to $16 \mathrm{ppm}$ of free iodine), was compared using a natural exposure trial on dairy cattle. The trial was based on National Mastitis Council guidelines and performed over 9 mo. Both teat dips contained $0.25 \%$ iodine. Product 2 reduced the infection rate $57.6 \%$ for major pathogens and $53.7 \%$ for minor pathogens, compared with the positive control. Product 2 gave highly significant reductions for Staphylococcus aureus, coagulase-negative staphylococci, and Corynebacterium bovis. Teat skin, teat ends, and teat hyperkeratosis were evaluated during trial. No significant difference in teat condition was observed between these 2 products.

(Key words: iodine, teat dip, free iodine, intramammary infection)

Abbreviation key: $\mathbf{N M C}=$ National Mastitis Council .

\section{INTRODUCTION}

Teat dips have been used for many years to reduce the number of infections induced by mastitis-causing bacteria [National Mastitis Council (NMC), 1996]. Iodine teat dips are very effective at reducing the spread of bovine mastitis. In this study, the efficacy of an experimental teat dip was compared with a positive control dip using a natural exposure clinical field trial. Both the control and experimental teat dips contained $0.25 \%$ available iodine. Based on a study by Murdough and Pankey (1993), the effectiveness of iodine germicides has little dependence on the iodine concentration. It has been reported (Gottardi, 1991) that the efficacy of iodine teat dips is greatly affected by the concentration of free iodine in the product. Free iodine is a measure

Received March 4, 2004.

Accepted September 17, 2004.

Corresponding author: Chris Foret, e-mail: chris.foret@ DeLaval.com. of the concentration of uncomplexed or molecular iodine as indicated in equation 1 . In equation 1 , iodide is used to complex iodine (Hemling et al. 2000).

$$
\left.\mathrm{I}_{3}^{-}(\text {complexed iodine }) \rightarrow \mathrm{I}_{2} \text { (free iodine }\right)+\mathrm{I}^{-}
$$

Nonionic surfactants are also commonly used to form an iodine complex. These mixtures are generally referred to as iodophors. Equation 2 shows the typical equilibrium for an iodophor:

$$
\begin{gathered}
\text { Surfactant: } \left.\mathrm{I}_{3}^{-} \text {(complexed iodophor }\right) \rightarrow \\
\mathrm{I}_{2} \text { (free iodine) }+\mathrm{I}^{-}+\text {surfactant }
\end{gathered}
$$

For this trial, product 1 contained 5 to 8 ppm of free iodine at $25^{\circ} \mathrm{C}$ and product 2 contained 12 to $16 \mathrm{ppm}$ of free iodine at $25^{\circ} \mathrm{C}$. The purpose of this study was to confirm that a new iodine teat dip that is based on higher free iodine technology (Foret and Hemling, 1999) showed superior performance compared with a similar product with lower free iodine.

\section{MATERIALS AND METHODS}

The trial was performed at a commercial dairy farm in Argentina from January to September 2002. Ninety Holstein cows, kept on a pasture, were used. The cows remained on the pasture except during milking. The herd was divided into 2 groups: group 1 ( 45 cows) was used to test product 1 (control group), and group 2 (45 cows) was used to test product 2 . Pasture grazing was supplemented with corn silage and protein concentrate. Both groups received the same feeding and milking routine. Ear tag numbers, colored collars, and paint on the back part of the udder were used to identify the groups. Cows with one or more lactations and 4 functioning quarters were randomly assigned to the 2 groups. The cows in the herd had an average of 2.5 lactations. As cows went into a dry period, new cows were added to the group to maintain a constant number of cows in each group.

The cows were milked twice daily. Before milking, the teats were washed with water and dried with a 


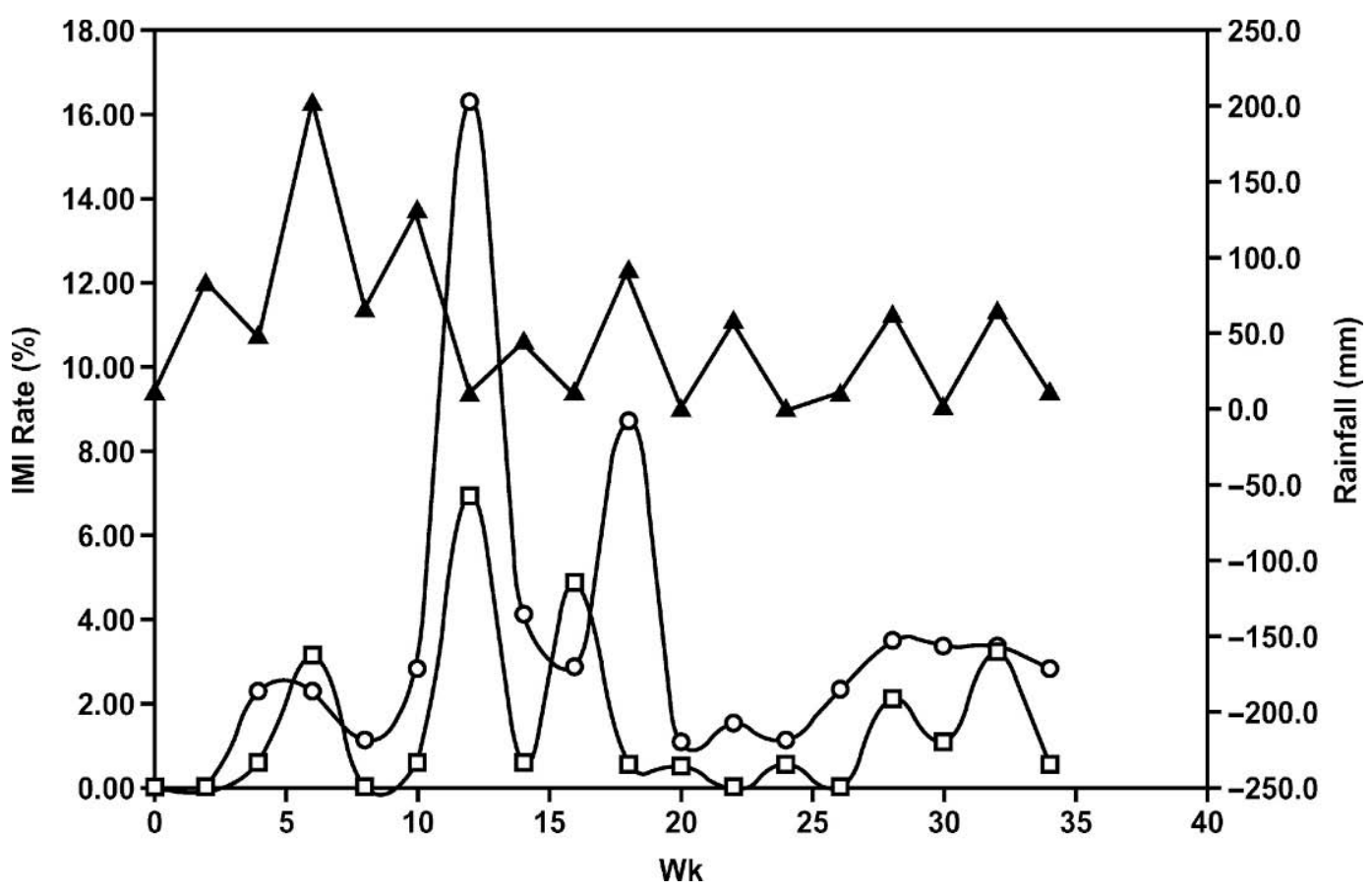

Figure 1. Percentage of intramammary infections for each 2-wk period for product 1 (Della Care, $\bigcirc$ ) and product 2 (New Della Care, $\square)$ with daily rainfall data $(\mathbf{\Delta})$.

single-service paper towel. No predip was used. After milking, the teats were dipped with the appropriate teat dip.

Because some infections can clear up in a short time, milk samples were obtained every 2 wk to provide an opportunity for more complete analysis of the infection rate reduction of the 2 products. Teat condition scores were also recorded every $2 \mathrm{wk}$. Somatic cell count was measured monthly.

\section{Sampling Schedule}

Single milk samples from each quarter were collected and analyzed every 2 wk during the trial. Cows were classified as having an infection when 2 consecutive samples showed at least $100 \mathrm{cfu} / \mathrm{mL}$ of the same organism. All quarters were eligible for new infections during the trial except those previously identified as infected with organisms of the same species.

At the beginning and end of the trial, the bacteriological status of mammary quarters was determined by collecting and culturing duplicate milk samples to confirm infections. A third sample was collected from specific quarters and cultured when results from the first 2 samples differed.

Bacteriological status was determined by culturing duplicate milk samples for new cows entering a group and for cows leaving a group.

\section{Collection of Milk Samples}

Before sampling, 2 or 3 streams of foremilk were discarded. Each teat apex was scrubbed for several seconds with a cotton pledget moistened with $70 \%$ alcohol. Teats on the opposite side of the udder from the technician were sanitized first, and milk samples were collected in reverse order in sterile, snap-cap plastic tubes and refrigerated at $5^{\circ} \mathrm{C}$ for $2 \mathrm{~h}$. Samples were then frozen for about 10 to $15 \mathrm{~d}$ before being cultured.

\section{Laboratory Culture Procedures}

Samples were taken from the freezer and thawed at room temperature. Ten microliters of each quarter sample was cultured at a rate of 4 samples per plate. Samples were cultured on trypticase soy blood agar media with 5\% blood and $0.1 \%$ esculin and on Edwards modified media. Bacteria were classified according to NMC recommendations (Hogan et al., 1999). Colony forming units were counted using a stereoscopic magnifying glass. Samples were declared positive when they had at least $100 \mathrm{cfu} / \mathrm{mL}$ of a given bacterial species.

A new IMI for a given pathogen was declared when the culture was positive in the same quarter in 2 consecutive samples. 


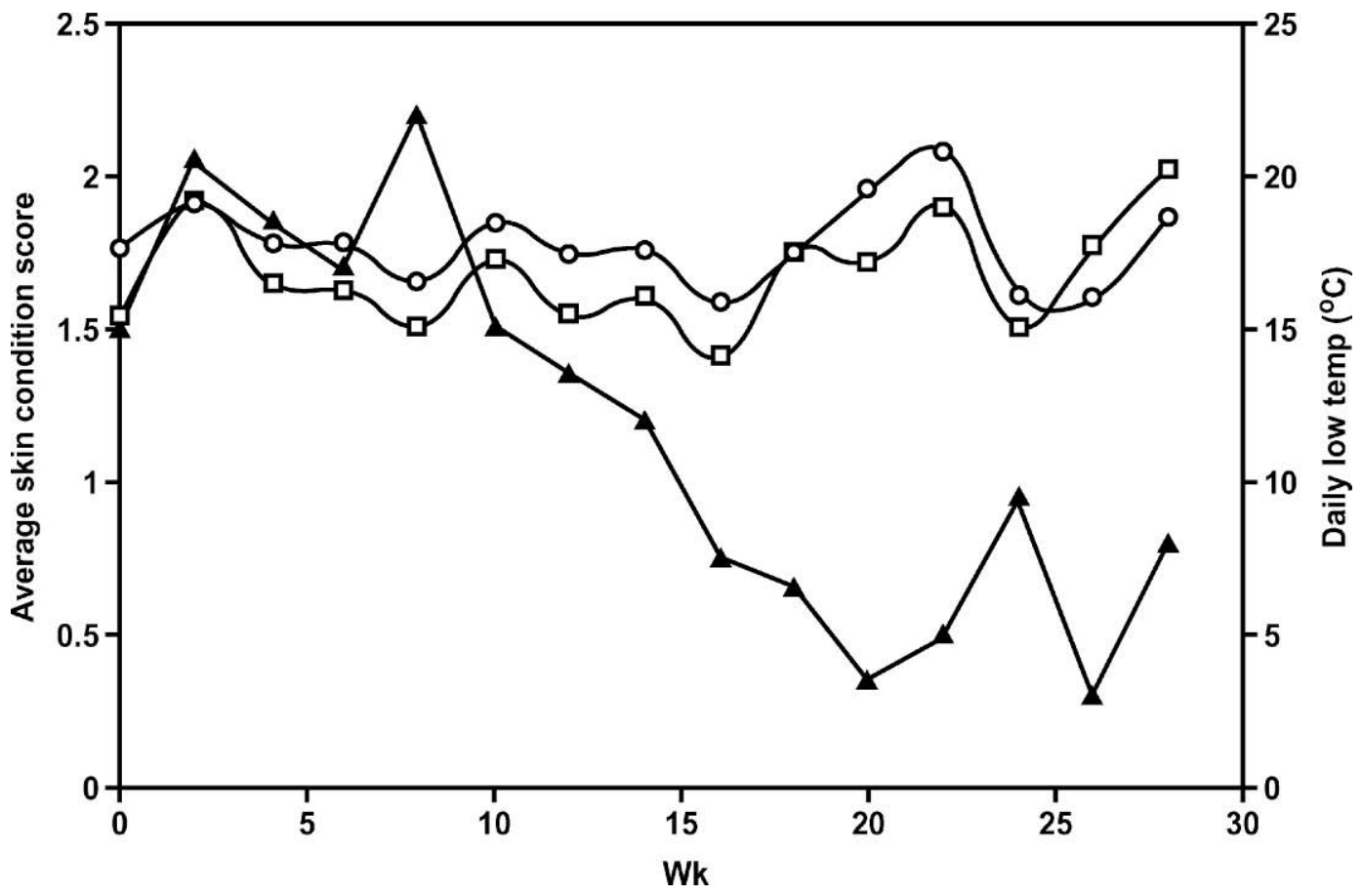

Figure 2. Average skin condition scores for product 1 (Della Care, $\bigcirc$ ) and product 2 (New Della Care, $\square$ ) with daily low temperature values $(\boldsymbol{\Delta})$. For skin condition scores, $1=$ teat skin is smooth, supple, free from scales, cracks, or chapping; $2=$ slight drying of skin with a superficial flaking; 3 = more severe drying with early cracks present; skin cracks do not have severe red fissures at the base; $4=$ more teat skin is chapped with pronounced cracks present; redness, indicating inflammation is present; some scabbed, healing lesions may be present; and 5 = severe skin damages with deep chaps and open ulcerative lesions or scabs.

\section{Weather Data}

The weather ranged from hot summer conditions, heavy rainfall during the fall months, and cold winter conditions. A HAT temperature and humidity monitor from Ryan Instruments (Redmond, WA) was used to record the exact temperature and humidity every hour at the farm site.

\section{Scoring of Teat Condition}

Characteristics of teat end, hyperkeratosis, and teat skin condition in test and control teats were scored every 2 wk throughout the trial. An ordinal scale was used. Visual and tactile observations were made. A more detailed discussion of teat condition is reported by Neijenhuis (2004). The statistical analysis of the teat condition data was performed on cows that were present throughout the first 6 mo of the trial.

\section{Product Description}

The teat dips were provided ready to use from DeLaval Inc. (Kansas City, MO). Product 1 (used as a positive control, Della Care, DeLaval Inc.) and product 2 (New Della Care, DeLaval Inc.) contained $0.25 \%$ available iodine and $2 \%$ glycerin. The new Della Care technology is described in United States patent 5,916,581 (Foret and Hemling, 1999). The positive control (product 1), was previously shown to result in a $75.6 \%$ reduction in infections in an experimental challenge protocol (Hemling and Winicov, 1994). The positive control was shown to be not significantly different from a $1 \%$ iodine product in a natural exposure trial (Bray et al., 1983).

\section{Statistical Methods}

The Student's $t$-test was used to evaluate the statistical difference between the 2 products. Hogan et al. (1990) described the procedure. The statistical probability of difference in IMI between the control and dipped quarters was measured from the value of $t$, such that $=$ $\left[\left(\mathrm{x}_{1} / \mathrm{n}_{1}\right)-\left(\mathrm{x}_{2} / \mathrm{n}_{2}\right)\right] /\left[\left(\mathrm{x}_{1}+\mathrm{x}_{2}\right) /\left(\mathrm{n}_{1} \mathrm{n}_{2}\right)\right]^{0.5}$ and where $\mathrm{x}_{1}=$ number of new IMI in control quarters, $x_{2}=$ number of new IMI in treated quarters, $\mathrm{n}_{1}=$ (number of control quarters)(biweekly periods of exposure), $\mathrm{n}_{2}=$ (number of treated quarters)(biweekly periods of exposure). Percentage reduction $=100\left[\left(\mathrm{x}_{1} / \mathrm{n}_{1}\right)-\left(\mathrm{x}_{2} / \mathrm{n}_{2}\right)\right] /\left(\mathrm{x}_{1} / \mathrm{n}_{1}\right)$. A teat dip is considered efficacious if the percentage reduction is at least $40 \%$.

The Mann-Whitney $U$-test (Mann and Whitney, 1947) was used to compare the teat condition scores of 


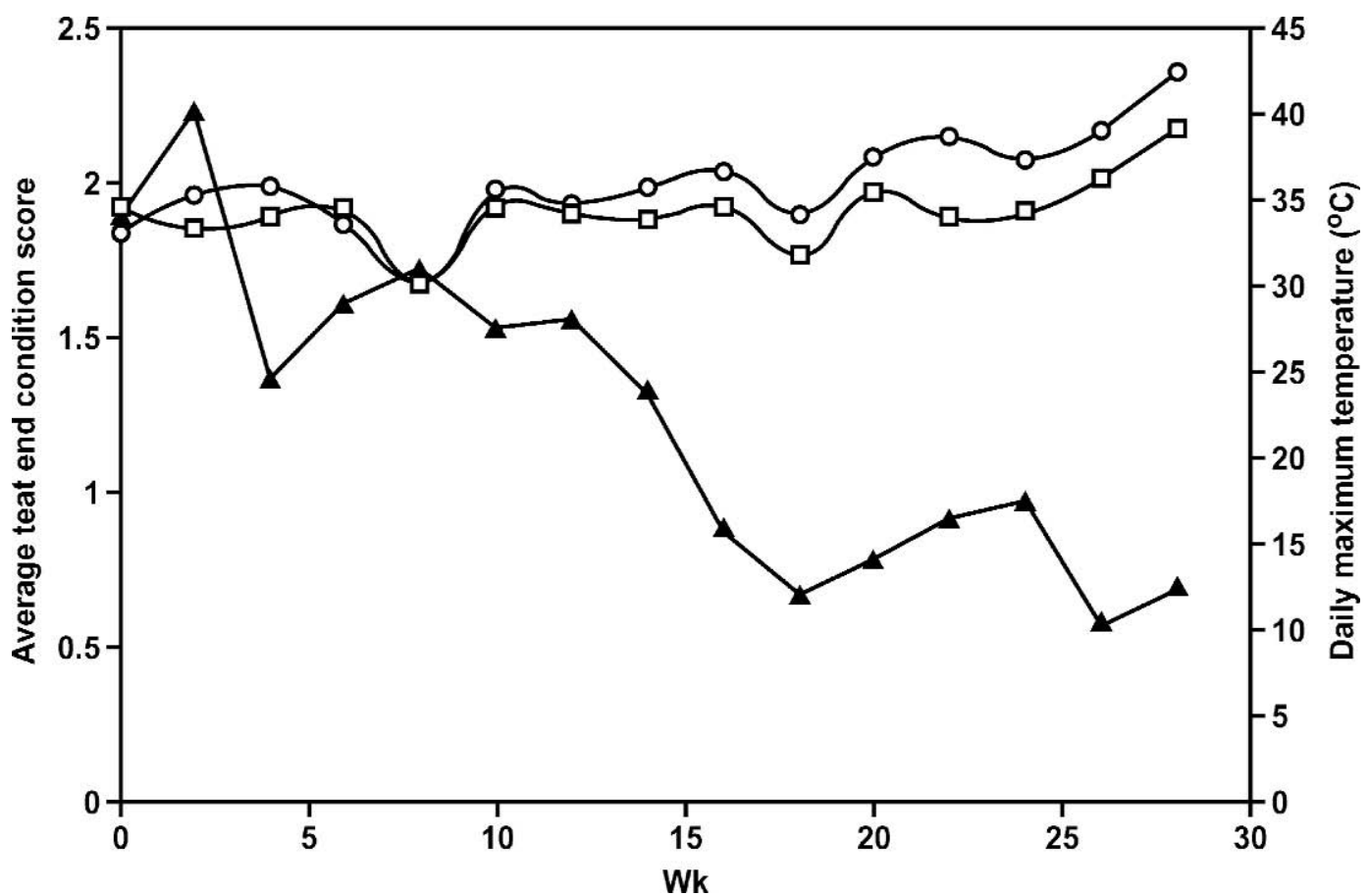

Figure 3. Average teat end score for product 1 (Della Care, $\bigcirc)$ and product 2 (New Della Care, $\square$ ) with daily high temperature values (A). For teat end orifice roughness scores, $1=$ smooth teat end and sphincter with no evidence of roughness; $2=$ slight irregularities of fringes of roughness near orifice; $3=$ teat end sphincter is moderately roughened with radial cracks; $4=$ teat orifice is significantly roughened with pronounced cracking; and $5=$ teat end is severely roughened and with deep irregular calluses.

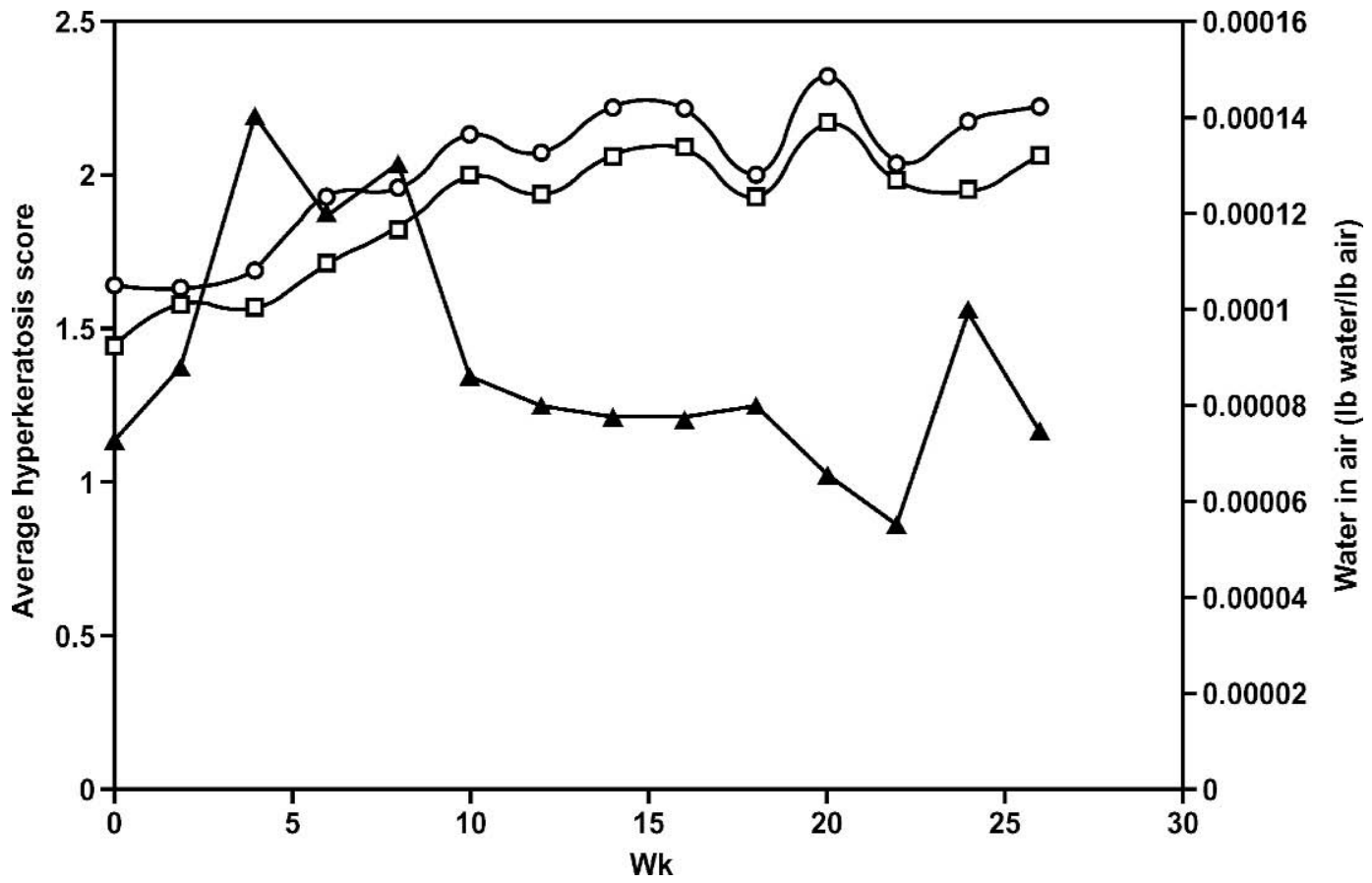

Figure 4. Average hyperkeratosis score for product 1 (Della Care, $\bigcirc$ ) and product 2 (New Della Care, $\square$ ) with daily water content in the $\operatorname{air}(\boldsymbol{\Lambda})$. For teat hyperkeratosis scores: $1=$ no ring; $2=$ slight raised ring; $3=$ moderate raised ring; and $4=$ thick raised ring. 


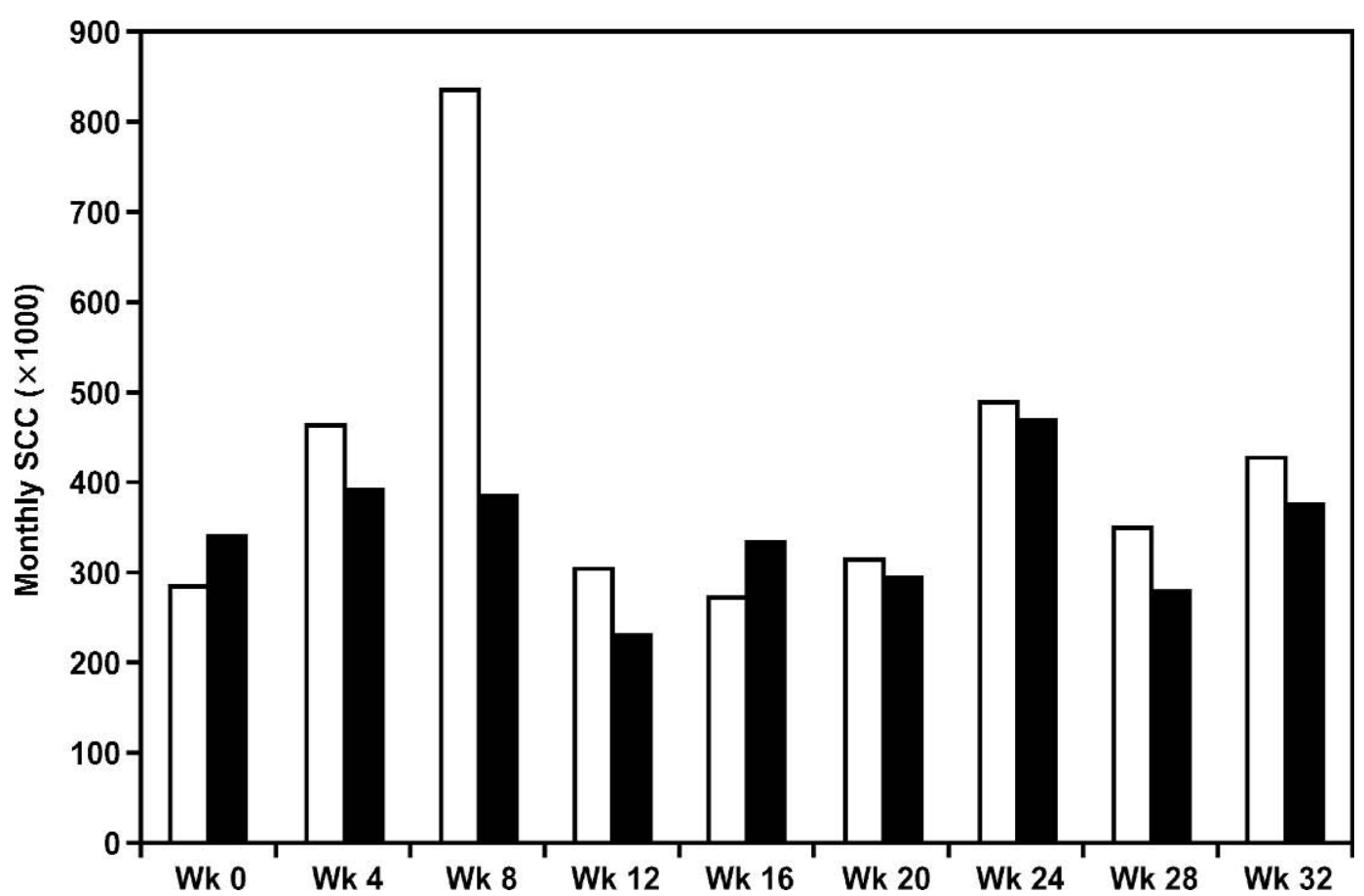

Figure 5. Monthly somatic cell count for product 1 (Della Care, $\square$ ) and product 2 (New Della Care, $\mathbf{\square}$ ).

the 2 groups. Each cow was treated as one data unit. The initial average score for all 4 teats of the cow was subtracted from the average score over wk 2 to 24 of the trial as shown in equation 3 .

Teat skin score cow \#1 =

(Average teat skin score during wk 2 to 24) - [3]

(Average teat skin score at wk 0)
For the score described by equation 3 , the subtraction of the wk 0 score was used to help compensate for any initial differences between the 2 groups of cows.

\section{RESULTS AND DISCUSSION}

The details of the infections observed during the trial are summarized in Table 1. A statistically significant

Table 1. Total number of new intramammary infections for all observed pathogens for control group 1 (product 1 , Della Care) and group 2 (product 2, New Della Care) over 9 mo.

\begin{tabular}{|c|c|c|c|c|c|c|c|}
\hline 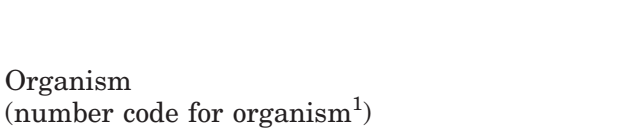 & $\begin{array}{l}\text { Infections } \\
\text { in group } 1 \\
\text { (control) }\end{array}$ & $\begin{array}{l}\text { Infections } \\
\text { in group } 2\end{array}$ & $\begin{array}{l}\text { Quarter- } \\
\text { biweek } \\
\text { at risk } \\
\text { for group } 1\end{array}$ & $\begin{array}{l}\text { Quarter- } \\
\text { biweek } \\
\text { at risk } \\
\text { for group } 2\end{array}$ & \% Reduction & $t$ & $P^{2}$ \\
\hline Staphylococcus aureus (1) & 26 & 10 & 2839 & 2978 & 63.3 & 2.81 & 0.005 \\
\hline Streptococcus spp. (nonagalactiae) (17) & 1 & 1 & 3051 & 3083 & 1.0 & 0.007 & 0.99 \\
\hline Streptococcus dysgalactiae (5) & 3 & 0 & 3048 & 3084 & 100 & 1.74 & 0.08 \\
\hline Total minor pathogens $(15+4)$ & 67 & 31 & 3060 & 3060 & 53.7 & 3.43 & 0.001 \\
\hline Coagulase-negative staphylococci (15) & 17 & 5 & 2968 & 3069 & 71.6 & 2.64 & 0.008 \\
\hline Corynebacterium bovis (4) & 50 & 26 & 2561 & 2691 & 50.5 & 2.97 & 0.003 \\
\hline Total contagious bacteria $(1+2+4)$ & 78 & 36 & 3060 & 3060 & 53.8 & 3.93 & 0.001 \\
\hline Total major environmental bacteria $(17+5+6)$ & 5 & 4 & 3060 & 3060 & 20.0 & 0.33 & 0.37 \\
\hline All organisms & 100 & 45 & 3060 & 3060 & 55.0 & 4.57 & 0.001 \\
\hline
\end{tabular}

\footnotetext{
${ }^{1}$ Number codes are based on the organism code used in Argentina.

${ }^{2} P=$ Two-tailed probability of a Type I error if the null hypothesis is rejected.
} 
$(P=0.006)$ reduction of $57.6 \%$ was observed for the combined major pathogens. Staphylococcus aureus was reduced $63.3 \%(P=0.005)$ compared with the positive control. Contagious organisms were reduced $53.8 \%(P=$ $0.001)$. The overall reduction in infection rate of $55.0 \%$ $(P=0.001)$ demonstrates the advantage of a product with higher free iodine. Very few infections of Streptococcus spp., Streptococcus uberis, and Streptococcus agalactiae occurred in either group, and therefore no significant difference was observed for these organisms. The herd had been consistently treated over the last 2 yr to eliminate Strep. agalactiae. A 71.6\% drop in CNS infections was observed.

Few infections were observed due to major environmental pathogens. No significant difference was found for the major environmental bacteria. The low incidence of major environmental pathogens is probably due to the cows remaining on pasture except during milking.

Corynebacterium bovis infections were common in the herd before the trial started. At the beginning of the trial, group 1 had 2 Staphylococcus aureus, 10 C. bovis, and 1 CNS infections; group 2 had 9 Staph. aureus and 13 C. bovis infections. The rate of clinical infections was very high before the trial started. Before the start of the trial, about $23 \%$ of the cows developed a clinical case of mastitis each month. During this pretrial period, a $0.4 \%$ iodine dip was applied, and newspaper was used to clean the teats. During the trial, the rate of new clinical mastitis cases fell to about $3 \%$ of the cows per mo. This drop in the rate of clinical infections is probably due to the application of a quality teat dip, the use of more absorbent paper towels, and more careful monitoring of the milking process.

Figure 1 shows the rate of infections for each product during the trial. The rate of infection increased around mo 3 . About $60 \%$ of the C. bovis infections occurred in wk 12 of the trial after a period of sustained heavy rainfall and muddy conditions. Although the rainfall did not cause an instant increase in the infection rate, the continuous high rainfall over wk 7 to 10 combined with a period of warm temperatures eventually seemed to cause an increase in IMI rate. Corynebacterium bovis is known to spread easily from cow to cow. Other increases in C. bovis infections observed during wk 16 to 18 seemed to correspond to a change to winter conditions. The increases in $C$. bovis seemed to be related to periods of environmental stress.

Corynebacterium bovis was the most common infection observed in this trial. The rate of infection was 0.016 to 0.031 C. bovis infections per quarter per mo (Table 1). A high rate of $C$. bovis infection is not uncommon in natural exposure trials. In a trial using a linear dodecyl benzene sulfonic acid teat dip, Pankey et al. (1985) observed 0.052 to 0.105 C. bovis infections per quarter per mo. Eberhart et al. (1983) recorded a rate of 0.055 and Nickerson et al. (1986) found 0.013 to 0.038 C. bovis infections per quarter per mo in natural exposure trials using $1 \%$ iodine teat dips. However, some natural exposure trials have shown a lower rate of infection. A rate of 0.005 C. bovis infections per quarter per mo was reported when using a $0.5 \%$ iodine dip (Peters et al., 2000). Because C. bovis inhabits the udder and teat ducts where the teat dip cannot reach and because the prevalence of $C$. bovis was extremely high at the beginning of the trial, it could take many months to reduce the $C$. bovis rate of infection to a lower level, even when using a very effective teat dip.

The equilibrium reaction for free iodine as expressed in equation 1 is temperature dependent. For any particular solution of complexed iodine, the free iodine concentration tends to increase as the temperature increases. This means that under low temperature conditions, the benefits of a high free iodine product will be more evident. During the first 4 mo of the trial, the average temperature was $14.8^{\circ} \mathrm{C}$, and product 2 reduced the number of infections by $48.2 \%$ compared with product 1 . During mo 5 to 9 the average temperature was $4.8^{\circ} \mathrm{C}$; product 2 reduced the infections by $63.6 \%$ compared with product 1 . Therefore a benefit was realized for the higher free iodine product under warm temperature conditions, and greater improvement in efficacy was observed during the colder months.

Infection rates tend to be higher during the warm months. This is because the warm temperatures are often accompanied by rain and mud. Also, bacteria growth rate is higher during warm weather. Therefore, although iodine dips are able to kill bacteria more easily at warmer temperatures, the bacteria are more active under these conditions.

Teats in both dip groups were scored for chapping, cracks, and other forms of irritation during the first 6 mo of the trial. There were only slight changes in teat end or teat skin characteristics during the trial. The average teat skin scores are listed in Figure 2 along with the low temperature values for the days that the scoring was measured. The average teat end scores are listed in Figure 3 along with the highest daily temperature values for the days on which the scoring was measured.

The Mann-Whitney $U$-test was used to compare the average skin and end scores for each product. No statistical difference was found for the teat end scores $(P=$ $0.21)$ and teat skin scores $(P=0.97)$.

Teat end hyperkeratosis is considered predominantly a function of milking machine effect (Britten et al., 2004). The hyperkeratosis scores shown in Figure 4 slightly increased in both groups during the trial. 
The average monthly SCC values for each group are shown in Figure 5. No significant difference in SCC was observed between the 2 groups.

\section{CONCLUSIONS}

Product 2 showed significantly superior reduction in new IMI compared with product 1 . Product 2 contains 12 to $16 \mathrm{ppm}$ of free iodine and product 1 contains 5 to $8 \mathrm{ppm}$. The reduction in new IMI was attributed to the higher free iodine contained in product 2 . A statistically significant improvement was observed for major pathogens $(57.6 \%)$. In addition, a statistically significant improvement was observed for CNS (71.6\%) and for $C$. bovis (50.5\%). Somatic cell count was generally similar for both products. No statistically significant difference was observed for the teat condition between the 2 groups. These results confirm that improved efficacy can be obtained for iodine teat dips that contain higher free iodine concentrations.

\section{ACKNOWLEDGMENTS}

The authors gratefully thank Monica Weinmayer for her help with the bacteriological analysis and Francisco Busso for his help with the field sampling.

\section{REFERENCES}

Bray, D. R., R. P. Natzke, R. W. Everett, and C. J. Wilcox. 1983. Comparison of teat dips with differing iodine concentrations in prevention of mastitis infection. J. Dairy Sci. 66:2593-2596.

Britten, A., N. Hanson, and J. Pedraza. 2004. Effect of Teat Dips on Hyperkeratosis. Pages 286-287 in Proceedings of Natl. Mastitis Counc. Annu. Mtg., Charlotte, NC. Natl. Mastitis Counc., Madison, WI.
Eberhart, R. J., P. L. LeVan, and L. C. Griel, Jr. 1983. Teat dip in a low infection prevalence herd. J. Dairy Sci. 66:1390-1395.

Foret, C., and T. C. Hemling. 1999. Iodine antimicrobial compositions containing nonionic surfactants and halogen anions. West Agro Inc., assignee. US Patent No. 5,916,581.

Gottardi, W. 1991. Iodine and iodine compounds. Pages 158-159 in Disinfection, Sterilization, and Preservation. 4th ed. S. S. Block, ed. Lea and Febiger, Philadelphia, PA.

Hemling, T. C., and M. Winicov. 1994. Effects of free iodine levels on the rate of new intramammary infections - An experimental challenge. Pages 330-331 in Proc. Natl. Mastitis Counc. Annu. Mtg., Orlando, FL. Natl. Mastitis Counc., Arlington, VA.

Hemling, T., C. Foret, M. McKinzie, and C. Hempstead. 2000. The effect of free iodine on the germicidal activity of iodine teat dips. Page 173 in Proc. XXI World Buiatrics Congr., Punta del Este, Uruguay. Sociedad de Medicina Veterinaria del Uruguay, Montevideo, Uruguay.

Hogan, J. S., D. M. Galton, R. J. Harmon, S. C. Nickerson, S. P. Oliver, and J. W. Pankey. 1990. Protocols for evaluating efficacy of postmilking teat dips. J. Dairy Sci. 73:2580-2585.

Hogan, J. S., R. N. Gonzalez, R. J. Harmon, S. C. Nickerson, S. P. Oliver, J. W. Pankey, and K. L. Smith. 1999. Laboratory Handbook on Bovine Mastitis. Natl. Mastitis Counc., Inc., Madison, WI.

Mann, N. R., and D. R. Whitney. 1947. On a test of whether one of two random variables is stochastically larger than the other. Ann. Math. Stat.18:50-60.

Murdough, P. A., and J. W. Pankey. 1993. Evaluation of 57 teat sanitizers using excised cow teats. J. Dairy Sci. 76:2033-2038.

National Mastitis Council. 1996. Pages 40-41 in Current Concepts of Bovine Mastitis, 4th ed. Natl. Mastitis Counc., Inc., Madison, WI.

Neijenhuis, F., J. E. Hillerton, C. O. Paulrud, M. D. Rasmussen, and J. Baines. 2004. Teat Condition and Mastitis. Pages 122-131 in Proc. Natl. Mastitis Counc. Annu. Mtg., Charlotte, NC. Natl. Mastitis Counc., Madison, WI.

Nickerson, S. C., J. L. Watts, R. L. Boddie, and J. W. Pankey. 1986. Evaluation of $0.5 \%$ and $1 \%$ iodophor teat dips on commercial dairies. J. Dairy Sci. 69:1693-1698.

Pankey, J. W., J. L. Watts, and S. C. Nickerson. 1985. Field studies on linear dodecyl benzene sulfonic acid teat dip. J. Dairy Sci. 68:1523-1530.

Peters, R. R., S. Komaragiri, M. J. Paape, and L. W. Douglass. 2000. Evaluation of $1.6 \%$ phenol as a premilking and postmilking teat dip in preventing new bovine intramammary infections. J. Dairy Sci. 83:1750-1757. 